\title{
THE CORRELATION BETWEEN ENGLISH LEARNING MOTIVATION AND ENGLISH PROFICIENCY ACHIEVEMENT OF ENGLISH STUDY PROGRAM STUDENTS
}

\author{
Debora Purwanti \\ Universitas Bengkulu \\ deborapurwanti9@gmail.com \\ Hilda Puspita \\ Universitas Bengkulu \\ puspitahilda@gmail.com \\ Mulyadi \\ Universitas Bengkulu \\ ladunimulyadi@gmail.com
}

\begin{abstract}
This study is aimed at identifying English learning motivation and English proficiency achievement. Then, the researcher would like to see the correlation between the students' motivation and their English proficiency achievement. The research was designed as quantitative correlation. Here, a total of 77 students were asked to complete the motivation questionnaire and set in a TOEFL test. The result of this research revealed that the English learning motivation of the students was in 'high' category. This can be seen from the grand total of mean 3.59 which indicated high intrinsic motivation as the dominant motivation. While, the scores of English proficiency achievement indicates that the students had 'medium' level of English Proficiency, the range score of medium level is 400-499. Another result showed that there was a significant correlation between English learning motivation and English proficiency achievement. It can be proven by $r_{\text {count }}(0.346)>r_{\text {table }}(0.224), 5 \%$ level of significance; there was a correlation between students with intrinsic motivation and their English proficiency achievement, $r_{\text {count }}(0.348)>r_{\text {table }}$ (0.233); while there was no correlation between students with extrinsic motivation and their English proficiency achievement, $r_{\text {count }}(0.307)<r_{\text {table }}(0.811)$. It means that the correlation between English learning motivation and English proficiency achievement was in 'weak' level.
\end{abstract}

\section{Key words: Motivation, English Proficiency, TOEFL, Correlation.}

\section{INTRODUCTION}

Motivation influences the success of students in learning a language. The students command adequate motivation in order to achieve their goals, needs and instincts. For students, motivation for academic achievement is very important.
The students are stimulated to successfully complete a task or achieving a goal by such motivation. Practically motivation becomes the reasons behind people's behavior and determines why they behave in a particular way (Amrai, et al. 2011:399). 
In educational perception, motivation has a correlation with learning and academic achievement (Mohammadi, 2006). There are different opinions of motivation. In the discipline of education, motivation is a tridimensional phenomenon consisting of individual's beliefs in ability in carrying out a specific task, reasons and goals of the individual in doing the task and the emotional response concerning carrying out the task (Hassanzadeh and Amuee, 2001). While psychologists have noted that motivation should be taken into account in education because of its effective relationship with new learning, abilities, strategies and behaviors (Shahraray, 2007), and they have presented motivation for academic achievement as one of the preliminary constructs for defining such type of motivation. Motivation for academic accomplishment is assessed to behaviors that lead to learning and achievement (Masaali, 2007).

In learning the target language, there are some types of motivation (Gardner \& Dorney, 2001). They are integrative, instrumental, intrinsic and extrinsic motivation. All types of motivation carry students to achieve certain goals in learning the target language especially English. Those goals can direct them to be students who have good proficiency in English. It can be seen from their score in English proficiency test. Some experts argue that learners' attitudes toward foreign language speaker groups influence their motivation and proficiency. The statements above are supported by the research from Trice (2007) that weak English language skills were perceived as one of the reasons why international students were isolated from local students and faculty members. These findings indicate that English proficiency is indirectly associated with academic performance of international students through its impact on other factors in the sociocultural and psychological dimensions.

Students' English proficiency is the ability of the students to speak or perform in English language. The ability of students' English proficiency can be seen by score. The score is taken from proficiency test. The test is in the form of TOEFL test or another test. All the score will show how far the students' ability in English.

In interviewing with some fifth semester students of English Study Program in Bengkulu University, the researcher found that there are some differences of students' motivation in learning English. The students' ability in English also shows some differences, it can be seen from their score in LHS. This is shown that they have different proficiency in English. The variation of the English proficiency that students' have may be influenced by some factors in learning. The one of the factors is motivation.

In conclusion, students' English learning motivation and their English proficiency particularly have a possible correlation which will impact students' result in a test. Every type of 
motivation has their part in influencing students in learning language process. In learning English process, students must know their motivation to support their goal. The motivation that they have during learning process will impact their ability in learning English. The ability of students get in TOEFL test is called English proficiency. It will show how the ability and knowledge of the students in learning English.

Here are several previous studies. First, the research of Emaliana (2011:8-9) “A Survey on Relationship Between Motivation and Achievement of English Department Students in State University of Malang". Analysis of the results revealed that instrumental motivation influences both high achievers and low achievers. In contrast the research of Pratiwi (2015) "The Learning Motivation and Preferred Learning Activities of Successful Students of English Education Study Program at Universitas Bengkulu". The finding showed that the successful students with integrative motivation were more dominant in learning English. The preferred learning activities of successful students have characteristic such as fun, entertaining and some of them are compulsory. There was no significant difference on the choice of preferred learning activities between the successful students who instrumentally and integrativelly motivated in learning English. This finding is also in line with Ellis (1994) cited in Li and Pan (2009) that learners with an integrative attitude have a compelling purpose for learning, which is an intrinsic force to learn a language and those learners will achieve more than the others.

The results of previous studies above have inspired the present research. It is tempting to explore further the findings in learners' motivation because Emaliana's investigation is in contrast to Pratiwi's investigation that instrumental motivation is more effective than the integrative one because of the second language functions as a foreign language, though an integrative motivation helps. Also, There is a view research previously which conducting two of these variables (learning motivation and English proficiency Achievement) to become one research whereas the students' learning motivation and English proficiency had relation one and another. The present research also will be different from the previous research because it will focus on two types of motivation, they are intrinsic and extrinsic motivation, while the previous studies are focused on integrative and instrumental motivation.

\section{METHOD}

This research used descriptive quantitative method. The specific design for this research was correlation. The correlation analysis method was used to analyze the relationship between two or more variables (Best and Khan: 1989). Arikunto (2010) also stated that correlation design is used to know the relationship that exist between two and 
among more than two variables. In this study, there were two quantifiable variables. First, English learning motivation whose variable was an independent one $(\mathrm{X})$. Second, English proficiency achievement whose variable was a dependent one (Y). The degree of relationship between the two variables was known by calculating product moment correlation coefficient.

The population of this research was all students in the fifth semester of English Study Program in Bengkulu University. They were chosen as the population because they are familiar with TOEFL test. They had learned all skills in English (listening, reading, speaking, and writing). They had taken grammar classes: Structure 1, Structure 2, and Structure 3. In addition, the access to do the research was also easy because the population is in the same study program (English Study Program) as the researcher. So, it was easy to find out the relationship between their English learning motivation and their English proficiency achievement. The sample of this research was 77 students.

Technique how to analyze the data was quantitative data by using questionnaire and TOEFL test. The questionnaire was used for assessing students' English learning motivation, intrinsic or extrinsic. The questionnaire was in the form of statements. It was adapted from the Gardner's Attitudes/Motivation Test Battery (AMTB) (2004 web) by taking only the questionnaire about the intrinsic and extrinsic motivation. TOEFL test was used for assessing students' English Proficiency. Here, the researcher only focuses on the students' competences (knowledge) in English, it was not included the students' performances in English. Here the researcher used the paper version of the TOEFL test (Phillips, 2001), but it was not include Test of Written English (TWE) because the TWE is not given with every administration of the paper TOEFL test.

\section{For Assessing English}

\section{Learning Motivation}

The percentage of the answer was found by using the following formula:

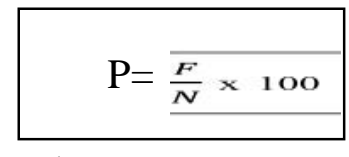

Where:

$\mathrm{P} \quad=$ percentage

$\mathrm{F} \quad=$ frequency of responses of each category for a statement

$\mathrm{N}=$ number of respondents

Table 1 Motivation level

\begin{tabular}{|c|c|c|c|}
\hline Scale & $\begin{array}{c}\text { Mean } \\
\text { Range }\end{array}$ & $\begin{array}{c}\text { Motivationa } \\
\text { l Level }\end{array}$ & $\begin{array}{c}\text { Score } \\
\text { Range }\end{array}$ \\
\hline 5 & $\begin{array}{c}\text { Strongly } \\
\text { agree }\end{array}$ & Highest & $4.50-5.00$ \\
\hline 4 & Agree & High & $3.50-4.49$ \\
\hline 3 & Moderate & Moderate & $2.50-3.49$ \\
\hline 2 & Disagree & Low & $1.50-2.49$ \\
\hline 1 & $\begin{array}{c}\text { Strongly } \\
\text { disagree }\end{array}$ & Lowest & $1.00-1.49$ \\
\hline
\end{tabular}

This motivation level is based on Best' theory (1970) in Manusak Degang' (2010:23).

\section{For English Proficiency} Achievement 
The range for students' TOEFL score was arranged in interval scale, showed in the table below:

Table 2 TOEFL Range Score

\begin{tabular}{|c|c|}
\hline $600-677$ & Very High \\
\hline $500-599$ & High \\
\hline $400-499$ & Medium \\
\hline $300-399$ & Low \\
\hline Under 300 & Lowest \\
\hline
\end{tabular}

\section{Statistical Analysis of Pearson Product Moment Correlation}

The pearson product moment correlation was used to investigate whether or not there was a significant correlation between English Learning Motivation and English Proficiency Achievement. The correlation calculation was done by using SPSS software version 21.00. The result of calculating ( $\mathrm{r}_{\text {count }}$ ) was compared to $\mathrm{r}_{\text {table }}$ in order to know which hypothesis was accepted and which was not. Briefly, the steps are as follows:

Hypothesis were reviewed.

$\mathrm{H}_{1}=$ There was significant correlation between students'

English learning motivation and their English proficiency achievement.

$\mathrm{H}_{0}=$ There was no significant correlation between students' English learning motivation and their English proficiency achievement.

Calculating the $\mathrm{R}_{\text {count }}$ by applying pearson product moment formula.

Where:

$r_{x y}=\frac{n \sum X Y-\left(\sum X\right)\left(\sum Y\right)}{\sqrt{\left\{n \sum X^{2}-\left(\sum X\right)^{2}\right\}\left\{n \sum Y^{2}-\left(\sum Y\right)^{2}\right\}}}$
Table 3 Five categories of correlation strength (Arikunto, 2010)

\begin{tabular}{|c|c|}
\hline Coefficient & Correlation category \\
\hline $0,800-1,00$ & High \\
\hline $0,600-0,800$ & Moderate \\
\hline $0,400-0,600$ & Rather weak \\
\hline $0,200-0,400$ & Weak \\
\hline $0,000-0,200$ & Very weak (no correlation) \\
\hline
\end{tabular}

\section{RESULT AND DISCUSSION Descriptive Analysis of Students' English Learning Motivation}

In this part, the researcher describes the answer of the first research question which was about the students' English learning motivation. The data has been gathered by using the questionnaire. The result of the first research question the mean score was $\mathbf{3 . 5 9}$ with predicate 'high' Motivation.

\subsubsection{Students English Learning}

Motivation (Intrinsic)

Based on the finding, it can be demonstrated that students' English learning motivation of intrinsic motivation was agree. It is showed on the table 4 that the average mean of this category was 4,17 with predicate 'High'.

\subsubsection{Students English Learning Motivation (Extrinsic)}

Based on the finding in this research, it can be demonstrated that students' English learning motivation of extrinsic motivation was agree. It is showed on the table 4 that the average mean of this category was 3.78 with predicate 'High'.

\section{Table 4 Summary on Students' English} Learning Motivation 


\begin{tabular}{|c|c|c|c|}
\hline No & Aspect & Mean & $\begin{array}{c}\text { Category/ } \\
\text { Predicate }\end{array}$ \\
\hline 1 & $\begin{array}{c}\text { Intrinsic } \\
\text { Motivation }\end{array}$ & 3.99 & High \\
\hline 2 & $\begin{array}{c}\text { Extrinsic } \\
\text { Motivation }\end{array}$ & 3.20 & Medium \\
\cline { 1 - 2 } Grand Total of sum & $\mathbf{7 . 1 9}$ & High \\
\hline Grand Total of Mean & $\mathbf{3 . 5 9}$ & \\
\hline
\end{tabular}

As can be seen from the table 4, the mean score of intrinsic motivation was 3.99, it was higher than the mean score of extrinsic motivation, 3.20. So, it can be concluded that most students in English Study Program of Bengkulu University in the fifth semester have intrinsic motivation in learning English.

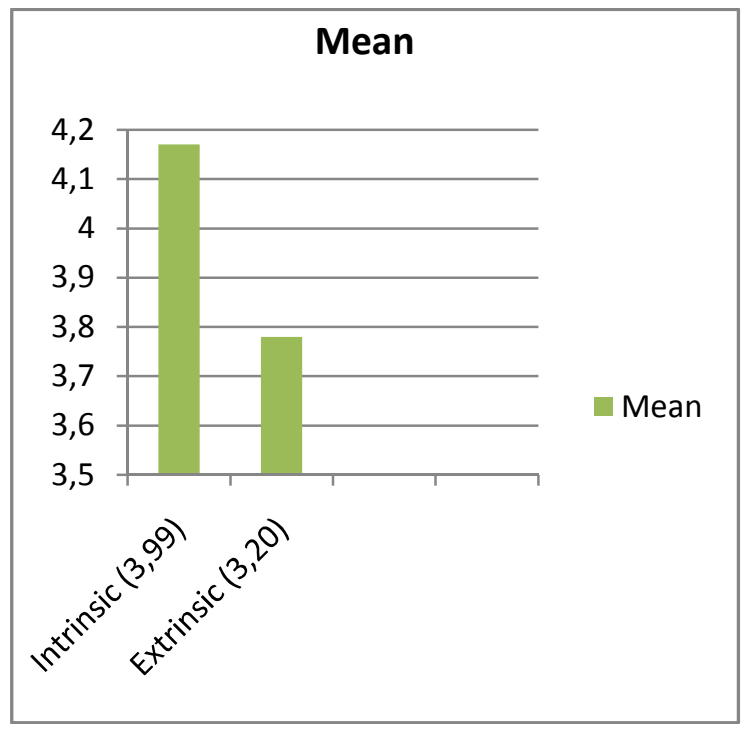

Figure 1

\subsubsection{The Percentage of students' Intrinsic Motivation and Students' Extrinsic Motivation}

Table 5

The Percentage of Students' Intrinsic and Extrinsic Motivation

\begin{tabular}{|l|l|l|l|}
\hline No. & Types of & Number & Percentage \\
\hline
\end{tabular}

\begin{tabular}{|c|c|c|c|}
\hline & motivation & $\begin{array}{c}\text { of } \\
\text { Students }\end{array}$ & \\
\hline 1. & $\begin{array}{l}\text { Intrinsic } \\
\text { students }\end{array}$ & 71 & $92.2 \%$ \\
\hline 2. & $\begin{array}{l}\text { Extrinsic } \\
\text { Students }\end{array}$ & 6 & $7.8 \%$ \\
\hline & Total & 77 & $100 \%$ \\
\hline
\end{tabular}

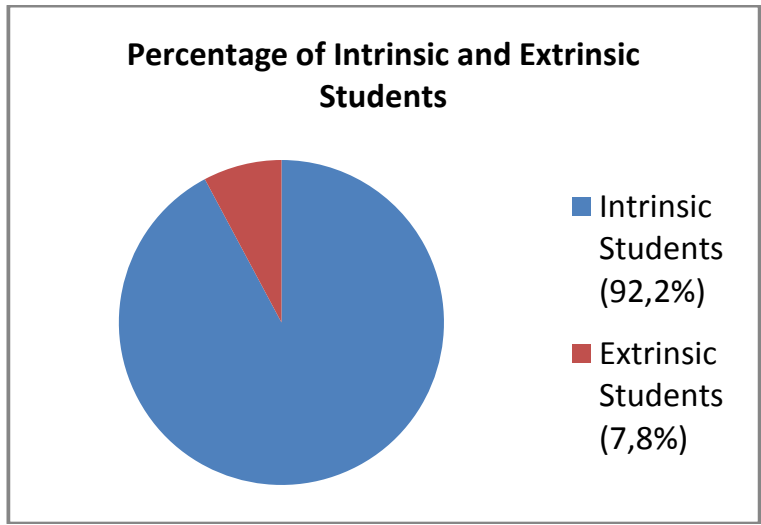

Figure 2

As can see in Table 5 that there were 71 students who had intrinsic motivation in learning English (92,2\%) and only 6 students who had extrinsic motivation in learning English (7,8\%). It can be concluded that the most motivation that students have in fifth semester of English Study Program in Bengkulu University was intrinsic motivation.

\subsubsection{Students score in English}

Proficiency Achievement

Table 6 English Proficiency achievement score

\begin{tabular}{|c|c|c|c|}
\hline Score & Category & Students & Percentage \\
\hline
\end{tabular}




\begin{tabular}{|c|c|c|c|}
\hline 600-677 & Very High & 0 & $0 \%$ \\
\hline $500-599$ & High & 10 & $12,99 \%$ \\
\hline $400-499$ & Medium & 44 & $57,14 \%$ \\
\hline $300-399$ & Low & 23 & $29,87 \%$ \\
\hline Under & Very Low & 0 & $0 \%$ \\
\hline
\end{tabular}

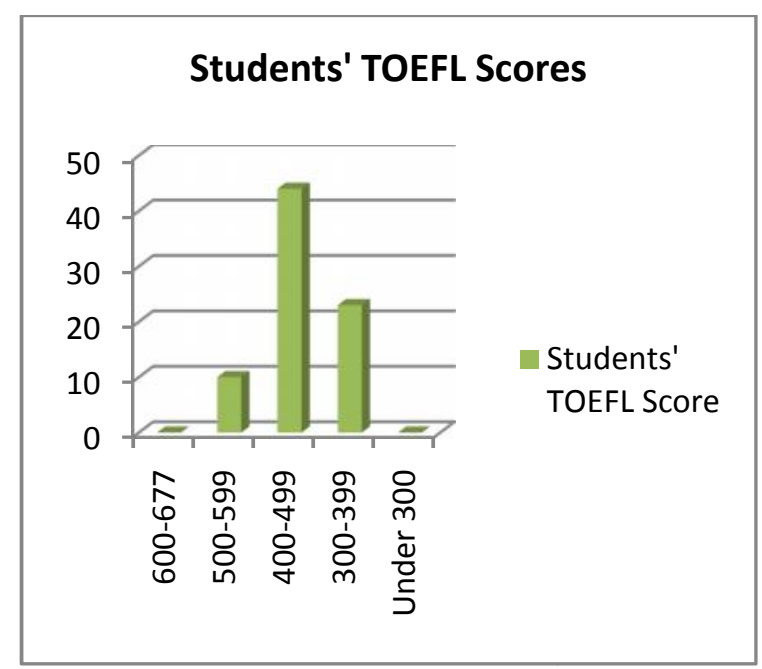

Figure 3

As can see in Table 6 that there were 10 students who got high achievements $(12,99 \%), 44$ students who got medium achievements $(57,14 \%)$, and 23 students who got low achievement $(29,87 \%)$. It can be concluded that the students' English Proficiency achievement of English Study Program in Bengkulu University was categorized at medium category.

\subsubsection{The Correlation between English Learning Motivation and English Proficiency Achievement}

The correlation coefficient was analyzed by using Pearson product moment correlation through SPSS software version 21.00 .

Note: Score of English Learning Motivation (X) Score of English Proficiency Achievement (Y)

Table 7 The Correlation between English Learning Motivation and English Proficiency Achievement

The summary result from the calculation SPSS software version 21.00 and Pearson product moment correlation can be seen in table below:

\begin{tabular}{|l|l|l|}
\hline & $\begin{array}{l}\text { Score of } \\
\text { English } \\
\text { Learning } \\
\text { Motivation } \\
\text { (X) }\end{array}$ & $\begin{array}{l}\text { Score of English } \\
\text { Proficiency } \\
\text { Achievement(Y) }\end{array}$ \\
\hline $\begin{array}{l}\text { Score of } \\
\text { English } \\
\text { Learning } \\
\text { Motivation } \\
\text { (X) } \\
\text { correlation } \\
\text { Sig.(2-tailed) }\end{array}$ & & 0.248 \\
N & & 0.000 \\
\hline $\begin{array}{l}\text { Score of } \\
\text { English } \\
\text { Proficiency } \\
\text { Achievement } \\
\text { (Y) }\end{array}$ & 0.248 & \\
correlation & & \\
Sig.(2-tailed) & & \\
N & & \\
\hline
\end{tabular}

$$
r_{x y}=\frac{n \sum X Y-\left(\sum X\right)\left(\sum Y\right)}{\sqrt{\left\{n \sum X^{2}-\left(\sum X\right)^{2}\right\}\left\{n \sum Y^{2}-\left(\sum Y\right)^{2}\right\}}}
$$

$\mathrm{r}=\frac{77(1479646)(3421-32979)}{\sqrt{77(152660)-(3421)^{2}} 77(14436771)-(32979)^{2}}$

$$
=0,248
$$


Based on table 6 , it can be seen that the coefficient correlation between the two variables $r_{\text {count }}(0.248)>r_{\text {table }}(0.224)$ with the degree significance of $5 \%$. It meant that the null hypotheses $\left(\mathrm{H}_{0}\right)$ was rejected and the alternative hypotheses $\left(\mathrm{H}_{1}\right)$ was accepted. Based on five categories of correlation strength (see Table 6), the degree of correlation was categorized as weak, which meant that there was a correlation between the two variables, and the correlation was in 'weak' level.

\subsection{Discussion}

\subsubsection{Motivation}

To answer the first research question about English learning motivation the data obtained from questionnaire (adapted from Gardner, 2004), it can be seen that the fifth semester students of English Study Program in Bengkulu University have all the two aspects of motivation. The two aspects that the researcher found in English learning motivation were, intrinsic motivation $(\mathrm{M}=3.99)$ and extrinsic motivation $(\mathrm{M}=3.20)$. Meanwhile, intrinsic motivation was the highest score.

From finding, it can be indicated that students in this sample show strong enthusiasm for English learning. The phenomenon may be due to the environmental fact that they are English Study Program students and it is the immediate medium of communication in the process of teaching and learning. Some students may think that it is necessary to learn
English hard because they are going to be an English teacher in the future.

Harmer (1991:3) explains the meaning of motivation as the "internal drive" that pushes somebody to do something. He said that, if people think that their goal is worth doing and attractive for them, then they try to reach that goal; this is called "the action driven by motivation".

This present research was in line with Eymur \& Geban (2011) who found that the highest motivation of pre-service chemistry teachers was intrinsic motivation. In addition, Unrau and Schlackman (2006) investigated the effects of intrinsic and extrinsic motivation on reading achievement for urban middle school students. They found that intrinsic motivation seemed to have a positive effect on reading achievement for Hispanic and Asian middle school students, whereas extrinsic motivation seemed to have a negative impact on reading achievement.

However, the result of this research was different from Khazaie \& Mesbah (2014) who found that extrinsic motivation was the dominant motivation of the students in Iran, implying that most of the students learned English for external reasons instead of intrinsic ones. The mean of extrinsic motivation was 3.29 and the mean of intrinsic motivation was 3.03.

This different findings may caused by some factors. Gardner (1982) in his socio-educational model 
notes that motivation is perceived to be composed of three elements. These are effort, desire and affect. Effort refers to the time spent studying the language and the drive of the learner. Desire indicates how much the learner wants to become proficient in the language, and affect means the learner's emotional reactions related to language study. Further, Littlewood (1953:53) noted that in language learning as in every other field of human learning, motivation is crucial force which determines whether a learner embarks on task at all, how much energy he devotes to it, and how long he perseveres. It is a complex phenomenon which includes many components: the individual's drive, need for achievement and success, curiosity, desire for stimulation and new experience, and so on.

\subsubsection{English Proficiency Achievement}

Concerning the second research question about English proficiency achievement, the data obtained from the TOEFL test (adopted from, Phillips, 2001) was analyzed on the data description section. The result of students' English in proficiency achievement are in a medium level, 400-499. In the "high" category showed that $12.99 \%$ from total number of students. In the "medium" category showed that the number of students is higher than the students in high category, it is $57,14 \%$ from number of students. Although there are some students are in the others category, such $29,87 \%$ students in "low" category, but the most students have category in medium level in English proficiency, so it can be said that English proficiency achievement of English Study Program students in Bengkulu University categorized in "medium" level.

However, there are two factors which influence the students achievement (Slameto, 2003). They are internal factors and external factors. Internal factors are intellegency factor, attention factors, and interest factors, motivation factor, maturity factor, etc. Meanwhile, external factors are family factors, school factors, and evironment factors. Motivation included in the two factors. So, it is one of many factors which can influence students' achievement internally and externally, especially in English Proficiency.

There are many factors which can influence the students' achievement, however the teacher or the lecturer have to know who are the students in order to make the students motivated to learn, especially for students in English major.

\subsubsection{The Correlation between English Learning Motivation and English Proficiency Achievement}

In order to answer the third research question, the researcher calculated by using SPSS Version 21.00. Based on the finding, it can be said that the English learning motivation does not really influence 
the students' English proficiency achievement. However, the correlation between students' English Learning motivation and English proficiency achievement is in 'weak' level.

This research result was in line with Chalermporn Choosri (2011) that used the different subject, variables and place to find the relationship between motivation and students' English learning achievement. He found in his research that there was significant correlation between motivation and students' English learning achievement of the second - year vocational certificate level Hatyai Technical college students. And, the results of the present study can be seen that there was a significant correlation between students' English learning motivation and their English proficiency achievement. The results of the present study can be concluded that low score of English learning motivation does not automatically mean that the students will get low score of English proficiency achievement and high score of English learning motivation does not always indicate that the students will also get high score for English proficiency achievement.

This research result was different from Almasa Mulalic, et al. (2016) investigated the motivational components and preferred learning components/methods. Mulalic, et al. used the different subject, method, and university. $\mathrm{He}$ found in his research that extrinsic motivation (M $=34.15$ ) was the highest motivational factor for the students. While, intrinsic motivation $(\mathrm{M}=12.97)$ was the lowest than extrinsic motivation. The correlation between the Motivational Components and the Preferred Learning components was significant.

The result from Mulalic, et al. above was different with the present study. The results of the present study showed that intrinsic motivation $(\mathrm{M}=$ 3.99) was more highest than extrinsic motivation $(M=3.20)$. The present study also showed that low score of English learning motivation does not automatically mean that the student will get low score of English proficiency achievement and high score of English learning motivation does not always indicate that the student will also get high score for English proficiency achievement.

Regarding to the fourth research question, the researcher calculated by using SPSS Version 21.00. Based on the finding, it can be said that the intrinsic motivation in English learning does not really influence the students' English proficiency achievement. However, the correlation between students' English Learning motivation and English proficiency achievement is in 'weak' level.

This finding contradicts with Dja'far et.al. (2016), who found that the there was a high positive correlation between students' motivation and their achievements in 
reading and writing aspects of ESP for most students from all class.

To answer the last research question, the researcher used SPSS Version 21.00. Based on the finding, it can be said that the Extrinsic motivation in English learning does not influence the students' English proficiency achievement. However, there was not correlation between students' English Learning motivation and English proficiency achievement.

This current study was different from Bambang Iswan (2017), who found that there was a correlation among motivation and students' achievement, and the correlation was in moderate level. His study was conducted on English Study Program students of IAIN Bengkulu. He was also found that extrinsic motivation is the most dominant motivation of English Study Program students of IAIN Bengkulu. It was different from the current study that found intrinsic motivation is the dominant motivation of the students in English Study Program of Bengkulu University.

The weak of the correlation between English learning motivation and English proficiency of English Study Program students which found in this research caused by some factors. At the beginning of this research, the researcher assumed that there will be significant or positive correlation between students' English learning motivation and their English proficiency achievement scores. However, the finding showed an insignificant finding which is far away from researcher's assumption. The negative finding of this research could be caused by some reasonable factors. Since English learning motivation is a factor among many other factors which can influence students' English proficiency achievement scores, it could be assumed that English learning motivation only gives little impact in students' English proficiency achievement scores. In this case, probably the students' of English Study Program in Bengkulu University are influenced by other factors in enhancing their English proficiency scores, such as; learning styles, learning strategies, facilitations, and etc. According to Slameto (2003) there are two factors that influence students' achievement. They are internal factors and external factors. Internal factors are intellegency factor, attention factors, and interest factors, motivation factor, maturity factor, etc. Meanwhile, external factors are family factors, school factors, and evironment factors.

Another factor caused the weak correlation between the students' motivation and their English proficiency achievements was the two variables were not consistent in the scores. This can be seen from the fact findings of this research that some students high motivated in learning English but their English proficiency achievement was low, and some of them low motivated in learning English but their English 
proficiency achievements was high. So, it can be concluded that low score of English learning motivation does not automatically mean that the student will get low score of English proficiency achievement and high score of English learning motivation does not always indicate that the student will also get high score for English proficiency achievement.

The strength of this research was this research was more complete because the sample of this research was taken from all classes of fifth semester that divided into two classes, $\mathrm{A}$ and $\mathrm{B}$ with total of the students was 77 students. The present study was also found English learning motivation and English proficiency achievement by the researcher, herself. Meanwhile, the limitation of this research was the correlation between students' English learning motivation and their English proficiency achievement was limited into simple correlation, while multiple correlations were not performed.

The result of this research can be used as the references for English teacher or lecturer in teaching in the classroom. They should consider the students' motivation in learning English in English major.

\section{CONCLUSION AND SUGGESTION}

Based on the result of the research that was described in the previous chapter, the researcher concludes that:
1. The students' English learning motivation was categorized into 'high' category. The mean score of intrinsic motivation was 3.99 , it was higher than the mean score of extrinsic motivation, 3.20. Intrinsic mean score was in 'high' category and extrinsic mean score in 'medium' category. So, it can be concluded that most of the fifth semester students in English Study Program of Bengkulu University have intrinsic motivation in learning English.

2. The students' English proficiency achievement score of fifth semester students in English Study Program in Bengkulu University was in medium category; 10 students got high achievement (12,99\%), 44 students got medium achievement $(57,14 \%)$, and 23 students got low achievement $(29,87 \%)$.

3. There was a significant correlation between students' English learning motivation and their English proficiency achievement at English Study Program in Bengkulu University. It can be proven by $\mathrm{r}_{\text {count }}$ $(0.248)>r_{\text {table }}(0.224), 5 \%$ level of significance. The fact that, the alternative hypothesis $\left(\mathrm{H}_{1}\right)$ was accepted while null hypothesis $\left(\mathrm{H}_{0}\right)$ was rejected. However, the correlation was 'weak'.

4. There was a significant correlation between Students' intrinsic motivation and their English proficiency achievement at English Study Program in Bengkulu 
University. It can be proven by $r_{\text {count }}$ $(0.348)>r_{\text {table }}(0.233), 5 \%$ level of significance. The fact that, the alternative hypothesis $\left(\mathrm{H}_{1}\right)$ was accepted while null hypothesis $\left(\mathrm{H}_{0}\right)$ was rejected. However, the correlation was 'weak'.

5. There was no significant correlation between students' extrinsic motivation and their English proficiency achievement at English Study Program in Bengkulu University. It can be proven by $r_{\text {count }}$ $(0.307)<r_{\text {table }}(0.811), 5 \%$ level of significance. The fact that, the alternative hypothesis $\left(\mathrm{H}_{1}\right)$ was rejected while null hypothesis $\left(\mathrm{H}_{0}\right)$ was accepted.

These are some suggestions that the researcher can propose after getting the result of the research:

1. Practical Contribution:

a. For students, this research will be expected to give information for them to know their English learning motivation level and to know their English proficiency achievement.

b. For the teacher or lecturer, this research will provide the feedback about how importance of English learning motivation for their students, in order to improve students' English proficiency achievement.

c. For researcher, this research can be a reference to the other researchers who wants to conduct further study about the relationship between English learning motivation and English proficiency achievement. The further researcher can try to conduct this research in different subject and location and also try to conduct this research by using different method like experimental research.

2. Theoretically, this research is expected to help in identifying the relationship between English learning motivation and English proficiency achievement.

\section{REFERENCES}

Amrai, at al. 2011. The Relationship between Academic Motivation and Academic Achievement

Students. Elseiver. PDF file. From: www.sciencedirect.com

Bernard, Jaclyn. 2010. Motivation in Foreign Language Learning: The Relationship between Classroom Activities, Motivation, and Outcomes in a University LanguageLearning Environment. Carnegie Mellon University. PDF file.

Carolina Lovato. 2011. Motivation In Second Language Acquisition Gardners Socio-Educational Model.

Choosri, Chalermporn. 2012. Relationship Between Motivation and Students' English Learning Achievement: A Study of The Second - Year Vocational Certificate Level Hatyai Technical College Students. Prince of Songkla University. PDF file.

Dörnyei. 2012. Motivation in second and foreign language learning. Thames Valley University, London. PDF file. 
Emaliana, Ive. 2012. A Survey on Relationship between Motivation and Achievement of English Department Students in State University of Malang. State University of Malang. PDF file.

Faris Keblawi. 2000. A review of language learning motivation theories.

Iswan, Bambang. 2017. The effect of Students' Language Learning Strategies and Motivations toward Their English Achivements at The English Department of IAIN Bengkulu. Thesis. Postgraduate Program of English Education Department of Teaching and Art. Bengkulu University.

Khazaie \& Mesbah . 2014. The Relationship between Extrinsic vs. Intrinsic Motivation and Strategic Use of Language of Iranian Intermediate EFL Learners. Theory and Practice in Language Studies, Vol. 4, No. 1, pp. 99-109, January 2014. ISSN 1799- 2591.

Kitjaroonchai, Nakhon. 2012. Motivation toward English language learning of students in secondary and high schools in education service area office 4, Saraburi

Province, Thailand. Science PG. Thailand.

Lemos \& Veríssimo. 2014.The relationships between intrinsic motivation, extrinsic motivation, and achievement, along elementary school. Procedia - Social and Behavioral Sciences 112 ( 2014 ) 930 - 938. ELSEIVER. PDF file.

Li and Pan. 2009. The Relationship Between Motivation And Achievement-A Survey Of The Study Motivation Of English Majors In Qingdao Agricultural University. English Language Teaching: China. PDF file. From:

Www.ccsenet.org/journal.html. Littlewood, W. 1995. Foreign and Second Language Learning. Cambridge University Press, Cambridge Language Teaching Library.

Manusak Degang. 2010. Motivation Toward English Language Learning of The Second Year Undergraduate Thai Students Majoring In Business

English At An English-Medium University. Master's project M.A. Bangkok: Graduate School, Srinakharinwirot University.

Mattarima \& Hamdan. 2011. Learners' Motivation And Learning Strategies In English Foreign Language (EFI) In Indonesian Context. Journal of Edupres. Universiti Teknologi Malaysia. PDF file.

Naemeh Nahavandi, Jayakaran Mukundan. 2013. Iranian EFL Engineering Students' Motivational Orientations

Towards English Language

Learning Along Gender And Further Education In Language

Institutes. International Journal Of Linguistics. ISSN 1948-5425.

Macrothink Institute.

Online Business Dictionary. 2013. Motivation. Retrieved May 23, 2013, from:http://www.businessdictionary. co $\mathrm{m} /$ definition/motivation.html. Pratiwi, Fitri. 2015. The Learning Motivation and Preferred Learning Activities of Successful Students of English Education Study Program at Universitas Bengkulu. University of Bengkulu. PDF file.

R. C. Gardner, Ph.D. 2004. Attitude/Motivation Test Battery: International AMTB Research Project. The University of Western 
Ontario, Canada. (English version).

R. C. Gardner. 1985. The Attitude/Motivation Test Battery: Technical Report (1985). University of Western Ontario.

Saheb, Véronique. 2014. Motivation in English as a Foreign Language Learning: A study of motivation toward English language learning in Stockholm'supper secondary schools for adults (KOMVUX). University of Halmstad, School of Humanities. PDF file.

Sandoval-Pineda, Angelica. 2011. Attitude, Wimolmas, Ratanawalee. A Survey Study of Motivation in English Language Learning of First Year Undergraduate Students at Sirindhorn International Institute of Technology(SIIT), Thammasat

University. Thammasat University: Thailand.

Wong Yin Mun. 2011. A Study Of Instrumental And Integrative Motivations As Factors Influencing Utar Third-Year Chinese Undergraduates In Learning Esl. Universiti Tunku Abdul Rahman.

Yousef Tahaineh, Hana Daana. 2013. Jordanian Undergraduates' Motivations and Attitudes towards Learning English in EFL Context. International Review of Social Sciences and Humanities. Vol. 4, No. 2 (2013), pp. 159-180. www.irssh.com. ISSN 2248-9010 (Online), ISSN 2250-0715. 